Title: Truth or Consequence: How the 1950s Quiz Show Scandal Shaped American Audiences Author(s): Claire Macleod

Source: St Andrews Law Journal, 1:1 (November 2020), 26-31

Published by: Institute of Legal and Constitutional Research, University of St Andrews

DOI: https://doi.org/10.15664/stalj.v1i1.2344

This work is protected under Creative Commons Attribution 4.0 International (CC BY 4.0) License 2021.

The Author(s) retain copyright holding, having permitted the St Andrews Law Journal to distribute (publish) their work. All written content, Copyright @ the Author(s)

The St Andrews Law Journal is an Open Access publication of the University of St Andrews, published by the Institute of Legal and Constitutional Research with support from the University of St Andrews Journal Hosting Service

All use subject to:

https://creativecommons.org/licenses/by/4.0/

ISSN 2634-5102 


\section{Truth or Consequence: How the 1950s Quiz Show Scandal Shaped American Audiences}

By Claire Macleod

|Preamble|

| This paper offers an overview of the 1950s American quiz show scandal that revolved around the 'rigging' of CBS and NBC programs The \$64,000 Question and Twenty-One during an unprecedented transformation and rapid growth of the postwar American media landscape. |

'I was involved, deeply involved, in a deception. The fact that I, too, was very much deceived cannot keep me from being the principal victim of that deception, because I was its principal symbol.'1

When Charles van Doren read out this prepared statement to Congress in 1959, his words would disillusion a nation. The dashing, young, Columbia professor had risen to fame through his success on a popular quiz show, Twenty-One, only to be forced to admit to the United States Congress that the game had been rigged and that America's intellectual heart-throb was a fraud. This revelation would not only shock and disappoint millions it would also prompt an amendment to the 1934 Communications Act making it a federal crime punishable by imprisonment to 'influence, pre-arrange, or predetermine' the outcome of 'a 'bona fide contest of intellectual knowledge'. ${ }^{2}$ It is difficult for modern viewers, who are so accustomed to televised deception for the sake of ratings, to understand the impact this case had on the American audience. How gullible could they have been to think that a popular quiz show sponsored by Geritol (a pharmaceutical that cured 'tired blood') could be anything but a sham? For the last few decades, the 1950's quiz show scandal has been consigned to, as contemporary D.A. Joseph Stone put it, 'errorriddled chapters in nostalgia picture books about television'. ${ }^{3}$ Recently,

${ }^{1}$ Congress, House, Committee on Interstate and Foreign Commerce, Investigation of Television Quiz Shows, 86th Cong., 1st Sess., November 2-6, 1959 (Washington, D.C.: U.S. Government Printing Office, 1960).

247 U.S.C. $§ 509$

3 Joseph Stone, Prime time and misdemeanors: investigating the 1950s quiz show scandal: a DA's account, (New Brunswick, 1992), p. 9. 
however, its ethical and legal precedent has been resurrected in light of growing concerns for the 'mass attention' paid to

companies like Google and Facebook whose algorithms inadvertently deceive large audiences for advertising revenue. ${ }^{4}$ Yet, the extent to which the quiz show scandal is applicable, both ethically and legally, to modern legislation is contingent on its historical context and use in case precedent. Apparent in this bizarre episode of legal history is the considerable injustice of the scandal itself but also the difficulty in effectively legislating against mass deception.

According quiz show host, Jack Narz, 'the night that $\$ 64,000$ Question was on, you could shoot a cannon down the street, 'cause nobody was on the street. Everybody was at home watching that show. ${ }^{5}$ This primacy of popular television programs are a feature of what Tim Wu referred to as the era of 'peak attention'. ${ }^{6}$ Radio had laid the groundwork in the first half of the century but the rapid introduction of television and Nielsen ratings into American homes would expand both the size of the American audience and their advertising potential. In 1956, with 72 percent of American homes owning a television, broadcasters could command the attention of up to 82.6 percent of those viewers on a single program. ${ }^{7}$

The quiz show concept, originally conceived in radio, was introduced to television with William Paley's CBS program, The $\$ 64,000$ Question. It became an instant success beating the former CBS heavyweight title, I Love Lucy within its first year and prompting copies from NBC. ${ }^{8}$ The show's sponsor, Revlon, would experience a two hundred percent increase in sales and would keep close tabs on contestants' ratings and their effect on product sales. Revlon exerted pressure on the show's producers to keep highly rated contestants on television and to 'stiff' the duller contestants. When NBC created its quiz show Twenty-One, as producer Daniel Enright stated, 'the first show was not rigged and the first show was also a dismal failure. It was just plain dull.' According

${ }^{4}$ Key argument in Tim Wu, The Attention Merchants, (New York, 2017), p. 207

5 Jack Narz interviewed in The American Quiz Show Scandal, Michael L. Lawrence, PBS Documentary (1991), https://www.youtube.com/watch?v=u6bPGl6y8qA\&t=627s\&ab_channel=TheDevil\%27sGa me, [1 November 2020]

${ }^{6} \mathrm{Wu}$, The Attention, p. 207.

7 Ibid

${ }^{8}$ George Brietigam, Keeping it Real: How the FCC Fights Fake Reality Shows with 47 U.S.C. 509, 22

CHAP. L. REV. 369 (2019)., p. 376. 
to Enright, 'the next morning the sponsor called [...] and told us in no uncertain terms that he never wanted to see a repeat of the previous night. And from that moment on, we decided to rig TwentyOne.' 9

On both Twenty-One and The $\$ 64,000$ Question, popular contestants would be given the answers and coached on how to behave in the 'isolation booth' so as to heighten the suspense. The most successful personality was, of course, the charming, clean-cut Charles van Doren who was brought on to defeat the uncharismatic Herbert Stempel. Van Doren 'was the kind of guy you'd love to have your daughter marr[y]' and, with his defeat of Stempel, would become the nation's intellectual hero. ${ }^{10}$ This national adoration would be brief, however, for Stempel and other 'stiffed' contestants would inevitably come forward with the disillusioning truth.

The revelation came first from the CBS show, Dotto, when a stand-by contestant, Edward Hilgemeier, noticed a notebook of answers in the dressing room of another contestant. His would be the first verified accusation of quiz show fixing and would add considerable credibility to Herbert Stempel whose accusations against CBS had up until then been dismissed as the behavior of a 'sore-loser'. After several more accusations were launched against the programs, New York District Attorney Joseph Stone convened a grand jury that heard the testimony of one hundred and fifty witnesses including former contestants and network producers. Of these witnesses, at least one hundred denied the accusations and perjured themselves in front of the jury. After ninemonths of testimony, the judge sealed the case only for it to be opened again by the US Supreme Court Subcommittee for Legislative Oversight. The Subcommittee would hear further testimony in Washington in October 1959 that saw Charles van Doren testify first to deny the rigging and then, in November 1959, confess his involvement. Ultimately, van Doren and a number of other contestants including a producer would be convicted of perjury but their sentences were

9 The American Quiz Show Scandal, https://www.youtube.com/watch?v=u6bPGl6y8qA\&t=627s\&ab_channel=TheDevil\%27sGa me, [1 November 2020]

10 Ibid. 
suspended and none faced serious legal consequences. ${ }^{11}$ Their punishments were handled in the court of official opinion which saw van Doren dismissed from Columbia and the producers (temporarily) exiled from the entertainment business. For their part, the sponsors emerged with doubled profits and zero consequences. ${ }^{12}$ Meanwhile, the American audience was left feeling betrayed and disillusioned with the medium of television.

It was in this atmosphere of disillusionment that Congress passed 47 USC $\S$ 509 'Prohibited practices in contests of knowledge, skill, or chance' to prevent future 'crass frauds'. The most fascinating element of the quiz show scandal and trials was the apparent absence of any law that specifically prohibited fixing a game show. Yet, for the last sixty years, the application of the statute that emerged from the trials has been limited in scope and applicability. ${ }^{13}$ Its weakness in practice was noted as early as 1966 when the producers of the show Hollywood Squares prompted celebrity guests with questions and answers in advance but were absolved of potential violation as the celebrities were not considered contestants and the 'inquiry revealed no evidence that the contestants themselves had been supplied with secret assistance.' 14 Despite this case clearly pre-determining the outcome of an 'intellectual contest' and deceiving an audience, the FCC sets a precedent for considerable administrative loopholes that allow for deception to occur so long as the contestant themselves are never knowingly given an unfair advantage.

In 1972, Gary F. Roth identified this administrative precedent as one of the key deficiencies in 47 USC $\S 509$ as it is 'looking to the letter of the law in its practical context rather than the spirit of the law in its moral frame.' 15 If the spirit of $\S 509$ was to prevent future mass televised deceptions for the gain of advertisers, its letter has so far limited its scope to preventing contestants from gaining specific advantages in a niche category of contests. More recent

\footnotetext{
11 Stone, Prime time, pp. 3-6.

12 Ibid. p. 329.

13 Brietigiam, 'Keeping', p. 379.

1414 FCC 2d at 976 (emphasis supplied), cited in Gary Franklin Roth 'The Quizzes and the Law: Fifteen Years after “Twenty-One” How Far Can They Go?', Performing Arts Review (1972), 3:4, p. 637.

15 Roth, 'Quizzes', p. 638.
} 
attempts to invoke $\S 509$ have occurred in reality television programs but have been hampered primarily by the stipulation that the contest must be 'intellectual'. In 2001, a Survivor contestant claimed that the producers had tampered with the voting process to keep another contestant with more favourable ratings. ${ }^{16}$ In 2013, one of the stars of Storage Wars claimed that producers had 'salted' the storage lockers with items that might enhance their interest. Both cases invoked 47 USC $\S 509$ to no avail and both settled out of court. ${ }^{17}$

Kimberlianne Podlas reasoned that 47 USC $\S 509$ does not apply to most reality shows today because of the notoriously difficult-to-prove stipulation of intent ('with intent to deceive the audience') and its specificity of 'intellectual contests' for which most reality TV does not qualify. ${ }^{18}$ George Brietigam's investigation of the statute has shown that the FCC has occasionally investigated television shows for possible violation but that its limited interpretation of 'intellectual skill' (that excludes singing and stand-up comedy) often dismisses these complainants. It also primarily enforces 47 USC $\S 509$ on rigged radio contests but private lawsuits from contestants rarely prove successful. ${ }^{19}$ In essence, what Congress passed in the disillusioned postscandal days of 1960 was legislation that functioned only in hindsight. 47 USC $\S 509$ is, as Roth put it, 'a series of obstacles to past practices which can never be used again' and 'a conglomeration of vague and uncertain words which make most actions by quiz show producers capable of being misinterpreted.'20

The 1950s quiz show scandal and the limitations of 47 USC $\S 509$ is, perhaps, a testament to what Google CEO Larry Page observed in 2013: 'Old institutions like the law and so on aren't keeping up with the rate of change that we've caused through technology....' Page went on to comment that 'A

\footnotetext{
${ }^{16}$ George Brietigam, 'Keeping it Real: How the FCC Fights Fake Reality Shows with 47 U.S.C. 509,' 22 CHAP. L. REV. 369 (2019)., p. 374.

17 Lauren Etter, 'The Lawyers', ABA Journal 10o, no. 12 (2014), p. 60.

${ }^{18}$ Kimberlianne Podlas, Primetime Crimes: Are Reality Television Programs "Illegal Contests" in Violation of Federal Law, 25 CARDOZO ARTS \& ENT. L.J. 141, 141-42 (2007), cited in Brietigam, 'Keeping', p. 374.

19 Brietigam, 'Keeping', p. 375

${ }^{20}$ Roth, 'Quizzes', p. 644.
} 
law can't be right if it's 50 years old, like it's before the internet. ${ }^{21}$ Television brought about an entirely new system of communication, entertainment, and deception in the short space of a decade. It was a new industry that quickly innovated to meet the demands of advertisers who had now inherited the systems of mass communication brought about by the 20th century wars. The quiz show scandal was a peculiar case of medium misuse that both preceded and precipitated industry legislation. The limitations of 47 USC § 509 are perhaps more understandable when considering the ad-hoc basis for their creation. An episode of mass deception that legislators could not have anticipated, limited in its applicability today by the industry's continual innovations for further deception.

${ }^{21} 1$ Jay Yarrow, 'Google CEO Larry Page Wants A Totally Separate World Where Tech Companies Can Conduct Experiments On People’, 16 May 2013, <https://www.businessinsider.com/google-ceolarrypage-wants-a-place-for-experiments-2013-

5 ?r=US\&IR=T?utm_source $=$ copylink\&utm_medium $=$ referral\&utm_content=topbar $>$ [8 November 2020] 


\section{Bibliography}

\section{Primary sources}

47 U.S.C. § 509. Prohibited practices in contests of knowledge, skill, or chance.

FCC v. American Broadcasting Co., Inc., 347 U.S.C. 284 (1954)

14 FCC 2d at 976 (emphasis supplied)

\section{Secondary Sources}

Brietigam. George, Keeping it Real: How the FCC Fights Fake Reality Shows with 47 U.S.C. 509, 22 CHAP. L. REV. 369 (2019)., p. 369-408.

Congress, House, Committee on Interstate and Foreign Commerce, Investigation of Television Quiz Shows, 86th Cong., 1st Sess., November 2-6, 1959 (Washington, D.C.: U.S. Government Printing Office, 1960).

Etter, Lauren, 'The Lawyers', ABA Journal 100, no. 12 (2014), pp. 58-63.

Podlas, Kimberlianne, Primetime Crimes: Are Reality Television Programs "Illegal Contests" in Violation of Federal Law, 25 CARDOZO ARTS \& ENT. L.J. (2007),

Roth. Gary Franklin 'The Quizzes and the Law: Fifteen Years after "TwentyOne" How Far Can They Go?', Performing Arts Review (1972), 3:4, pp. 629-654.

Stone, Joseph, Prime time and misdemeanors: investigating the 1950s quiz show scandal: a DA's account, (New Brunswick, 1992)

Tedlow, Richard S., Intellect on Television: The Quiz Show Scandals of the 1950s, American Quarterly, Autumn, 1976, Vol. 28, No. 4 (Autumn, 1976),pp. $483-$ 495

The American Quiz Show Scandal, Lawrence, Michael L., PBS Documentary (1991),https://www.youtube.com/watch?v=u6bPGl6y8qA\&t=627s\&ab_channel=T heDevil\%27sGame, [1 November 2020]

Wu, Tim The Attention Merchants, (New York, 2017)

Yarrow, Jay, ‘Google CEO Larry Page Wants A Totally Separate World Where Tech Companies Can Conduct Experiments On People', 16 May 2013, <https://www.businessinsider.com/google-ceo-larry-page-wants-a-placeforexperiments-2013- 
5 ? $r=U S \& I R=T$ ?utm_source $=$ copylink\&utm_medium =referral\&utm_content=topba $\mathrm{r}>$ [8 November 2020]

Zuboff, Shoshanna, The Age of Surveillance Capitalism: The Fight for a Human Future at the New Frontier of Power, (New York, 2019 